\title{
Student Demographics and Their Effects on Risky Sexual Behaviors and Poor Condom Use Pattern in Two Departments of a Nigerian University
}

\author{
Matthew J Okonta ${ }^{1}$, Chukwuemeka M Ubaka ${ }^{1, *}$, Nnana O Arukwe ${ }^{2}$ \\ ${ }^{1}$ Department of Clinical Pharmacy and Pharmacy Management, Faculty of Pharmaceutical Sciences, University of Nigeria, Nsukka, \\ Nigeria \\ ${ }^{2}$ Department of Sociology and Anthropology, Faculty of The Social Sciences, University of Nigeria, Nsukka, Nigeria \\ *Corresponding author: pharmubk@yahoo.com
}

Received March 19, 2013; Revised April 24, 2013; Accepted April 27, 2013

\begin{abstract}
This study was conducted to assess the level and association of demographic factors on risky sexual behaviors and pattern of condom use among students of a Nigerian university. Final and penultimate year students in University of Nigeria were recruited and purposively sampled. Using a well structured and pre-validated questionnaire, questions on HIV awareness, sexual experiences and condom use were asked and responses collected. Data obtained were analyzed using descriptive statistics and analysis of variance. Exactly 524 students (mean age, 24 years; mean sexual debut age 19 years) participated. More females than male students had bisexual or homosexual partners ( $4.8 \%$ vs. $0.7 \%$, p < 0.01$)$; did not use a condom in the most recent sex $(48.3 \%$ vs. $22.9 \%$, p < $0.01)$ and in the last twelve months (31.5\% vs. $11.7 \%$, p < 0.05$)$; had been forced for sex $(23.2 \%$ vs. $18.7 \%$, p < $0.05)$. More male students did not know their status ( $37.1 \%$ vs. $25.7 \%, \mathrm{p}<0.05)$; had oral and anal sex $(41.3 \%$ vs. $27.3 \%, \mathrm{p}<0.01)$. As regards age at first sex, students who debuted earlier $(\leq 19$ years $)$ performed oral/anal sex $(53.6 \%$ vs. $40.1 \%, \mathrm{p}<0.05)$, did not use a condom during that first $\operatorname{sex}(70.1 \%$ vs. $45.4 \%$, p < 0.01$)$ and have had more than five sexual partners since then $(38.5 \%$ vs. $10.1 \%$, p $<0.01)$. This study showed that being male was associated with poor awareness of the virus and risky sexual behaviors and being female was associated with poor/inconsistent condom use. Also having started sex at an early age and being single was linked with risky behaviors. Such behaviors could be cautiously put in check by re-introducing HIV/AIDS prevention awareness strategies in universities.
\end{abstract}

Keywords: condom, gender, HIV, sexual behavior, students

\section{Introduction}

Acquired Immunodeficiency Syndrome (AIDS) is the African continent's biggest scourge and is presently without a cure. Two-thirds of the people living with HIV are from sub-Sahara Africa [1]. Estimates do not seem to favor this region as it leads in all HIV/AIDS indices ranging from adult prevalence (5\%), people living with HIV (22.0 million), newly infected persons (1.9 million) and deaths due to AIDS which is put at 1.5 million [1]. A large proportion of those at risk of acquiring HIV are youths, especially those involved in unprotected sex, illicit drug use and prostitution [2]. It is quite alarming that people no longer use condoms possibly due to religious inclination (e.g. Catholicism, which teaches against contraceptive use) and perceived poor effectiveness and side effects they cause. Also nonchalant attitude by youths towards condom use may be contributory to rise of new infections. Every day, an estimated 6000 youths are infected with HIV globally and of the 15-24 year old young people living with HIV, 63 per cent are in subSaharan Africa $[3,4]$. There is a need to encourage youths to curb risky sexual behavior and to take the test. Some studies have been conducted on sexual behaviors and condoms use pattern among youths in various African settings. A study in Malawi showed that there was a poor rate of HIV testing (19\%) among university students and a considerable number of the students had multiple sexual partners in the last 12 months [5]. A similar study in Madagascar, showed that most $(80 \%)$ of the students had sex before and only $6 \%$ used condoms consistently in the last 12 months citing reasons such as steady partners and decrease of pleasure [6]. Some Nigerian studies showed that only about $30 \%$ students in a Nigerian university had ever been tested for HIV and some students had over three sexual partners at a time $[7,8]$. These recent statistics among young people in an enlightened setting shows that the awareness and attitude towards the disease is very poor.

The control of new infections in Africa is an emerging focus and basic prevention services that have been advocated to be effective are; education about risks of HIV, Voluntary Counseling and Testing, access to condoms, treatment for sexually transmitted infections, strategies to prevent mother to child transmission of HIV and harm reduction programmes for injecting drug users [9]. Condom use provides $80 \%$ protection against HIV, 
compared with non-use, if used consistently [10]. There are also claims that irrespective of other risky sexual behaviors, consistent condom use has been demonstrated to be an effective means of preventing the acquisition and transmission of HIV and other STDs [11,12]. Consistent condom use among youths has been found to be poor in most African settings with more than half of them indulging in unsafe sex, especially in young women $[13,14]$. There is therefore a need to assess the level of HIV/AIDS awareness and fashion out new strategies (or further modify and implement old ones) to reduce the spread of the virus among vulnerable youths.

Some studies have singly analyzed the effect of gender and age only on sexual experiences of students in universities, but however, none has compared these sexual behaviors and awareness on a holistic demographic platform. This study however was aimed at (1) evaluating students' attitude towards HIV/AIDS and condoms, and their sexual behaviors (2) assessing the effect of demographic variables (age, age of sexual debut, gender and marital status) on students' attitude towards sex and HIV/AIDS and their sexual experiences.

\section{Methods}

\subsection{Study Site}

The University of Nigeria, Nsukka campus was used for this study. It is the country's first government owned University and it is the biggest in the South Eastern Region. It admits students from all parts of the country though majority is natives of the Igbo tribe of South Eastern Nigeria. It is the main campus and boasts of 12 faculties and about 150 departments. However, of all the departments in this campus, very few are taught about HIV/AIDS as a course or course topic in their academic curriculum. Such examples are the departments of Pharmacy and Sociology/Social work.

\subsection{Study Design}

The survey was cross sectional in nature to assess students' views on their sexual lives. It assessed the attitude and experiences of students towards sexuality, HIV, condom use and their related factors. It was conducted between the months of November and December 2011. It incorporated the use of students from the Departments of Pharmacy and Sociology/Social Work. Pharmacy curriculum contains courses which concentrate on the pathophysiology and clinical aspects of diseases of which AIDS is a core subject. Sociology and social work department teach students social care of diseased people, even sick or diseased people. They conduct hospital postings for students in health care centers to enable them learn techniques of care for aged and sick people.

\subsection{Study Instrument}

A 4-domain and 20-item questionnaire was prepared using questionnaires in the Malawi and Madagascar studies [5,6]. Slight modifications in style of questions asked were made. Using a pre-test of 20 students from a non-participatory department, the questionnaire was face validated by experts in social research at the University.
The questions were grouped in four domains namely: general information, knowledge of HIV/AIDS, sexual experiences and behaviors, and condom use. All questions were in English and asked in the simplest vocabularies excluding all medical terms as much as possible.

\subsection{Study Procedure}

An ethical approval was obtained from the Department of Students Affairs, University of Nigeria, Nsukka. The study targeted only students in their penultimate and final years of the Departments of Pharmacy and Sociology/Social Work, because they had been taught topics on HIV/AIDS according to the curriculum. A purposive sampling technique was employed, where all the students in these classes $(n=631)$ were eligible for participation. Students from each class were assembled after a compulsory $11 \mathrm{am}$ lecture and all told of the survey. However, details of the survey nor questionnaires were not revealed. Recruited participants were re-briefed on confidentiality of information and oral consent obtained from all willing participants. Students who were not willing to participate were excused from the study and reassured no punishment would be meted out to them. The students were put in two large auditoria and spaced well to reassure confidentiality of information to be provided. Questionnaires were administered and sufficient time was given for filling. After filling, participants were told to put their completed questionnaires into a large sealed ballot box and to leave the halls. No honorarium was offered or given to the participating students.

\subsection{Statistical Analysis}

Questionnaires were collected, re-arranged according to departments and data was analyzed using the 2007 Microsoft Excel and the SPSS (version 16, Chicago, USA). Data were coded into the Excel and re-coded again to check for consistency. The coded data were then loaded into the SPSS and analyzed with descriptive statistics. Mean and percentages were calculated for demographic data, knowledge of HIV, sexual experiences and behaviors and condom use patterns. Demographic percentages were generated by controlling for the independent variable and using frequency calculations. Reliability estimates of sections of the questionnaire were computed and reported using their Cronbach alpha. An independent sample t-test and Analysis of Variance were used to test differences between demographics of students of both departments. To analyze differences in responses to survey questions by demographics, cross tabulation and relevant chi-square tests were conducted. Statistical significance (one-sided) at $\mathrm{p}$-values of less than 0.05 was considered.

\section{Results}

\subsection{Demographic Characteristics of Student Participants}

A total of five hundred and twenty four (524) students from the two departments participated in the study from a sample of the combined classes' size of 631, giving a response rate of $83.0 \%$. Majority (i.e. 88 students; $82.2 \%$ ) of the 107 non-responders were students absent from 
classes when the survey was being conducted, while the remainder 19 students declined participation citing personal reasons. Among participants, there were more females than males $(56.2 \%$ vs. $43.8 \%$, p < 0.05$)$ and their mean age was 24.79 years (range $19-44$ years). The mean age at first sex as reported by students with sexual experience was 19.59 years with majority $(57 \%$, p < 0.01$)$ of them being younger than 19 years when they had their first sexual intercourse. Also majority $(88.9 \%, \mathrm{p}<0.01)$ of the students used in this study were single, but there were no significant differences in gender, age, age of first sex or marital status of the students of the two departments sampled (Table 1).

Table 1. Demographic Characteristics of students of Pharmacy and Sociology students, University of Nigeria, Nigeria

\begin{tabular}{|c|c|c|c|c|c|c|c|}
\hline Variable & \multicolumn{2}{|c|}{ Pharmacy $(\mathrm{n}=319)$} & \multicolumn{2}{|c|}{$\begin{array}{c}\text { Sociology } \\
(\mathrm{n}=205)\end{array}$} & \multicolumn{2}{|c|}{$\begin{array}{c}\text { Total } \\
(\mathrm{n}=524)\end{array}$} & P-values \\
\hline \multicolumn{8}{|l|}{ Age, years } \\
\hline Mean (SD) & \multicolumn{2}{|c|}{$24.73(2.47)$} & \multicolumn{2}{|c|}{$24.89(3.31)$} & \multicolumn{2}{|c|}{$24.79(2.82)$} & \\
\hline Range & \multicolumn{2}{|c|}{$19-44$} & \multicolumn{2}{|c|}{$19-44$} & \multicolumn{2}{|c|}{$19-44$} & 0.601 \\
\hline \multicolumn{8}{|l|}{ Age of first sex } \\
\hline Mean (SD) & \multicolumn{2}{|c|}{$19.54(4.19)$} & \multicolumn{2}{|c|}{$19.58(3.33)$} & \multicolumn{2}{|c|}{$19.56(3.84)$} & 0.875 \\
\hline Range & \multicolumn{2}{|c|}{$5-28$} & \multicolumn{2}{|c|}{$8-27$} & \multicolumn{2}{|c|}{$5-28$} & \\
\hline Gender & $N$ & $\%$ & $N$ & $\%$ & $N$ & $\%$ & \\
\hline Male & 146 & 45.8 & 84 & 40.4 & 230 & 43.8 & $<0.05^{\mathrm{a}}$ \\
\hline Female & 173 & 54.2 & 121 & 59.6 & 294 & 56.2 & \\
\hline \multicolumn{8}{|l|}{ Marital Status } \\
\hline Single & 281 & 88.0 & 185 & 90.2 & 466 & 88.9 & \\
\hline Cohabiting & 4 & 1.3 & 0 & 0 & 4 & 0.8 & \\
\hline Married & 34 & 10.7 & 20 & 9.8 & 54 & 10.3 & \\
\hline Divorced & - & - & - & - & - & - & $<0.01^{\mathrm{b}}$ \\
\hline
\end{tabular}

${ }^{\mathrm{a}} \mathrm{p}<0.05$, t-test; ${ }^{\mathrm{b}} \mathrm{p}<0.01$ for ANOVA * $\mathrm{p}$-values are for the total demographic variables.

Table 2. Demographic association of students' awareness and knowledge of HIV status, testing and testing centers in a Nigerian university

\begin{tabular}{|c|c|c|c|c|c|c|c|c|}
\hline \multirow{3}{*}{$\begin{array}{c}\% \text { response to survey } \\
\text { questions }\end{array}$} & \multicolumn{8}{|c|}{ Percentage response $(\%)$} \\
\hline & \multicolumn{2}{|c|}{ Gender } & \multicolumn{2}{|c|}{ Age, yrs } & \multicolumn{2}{|c|}{ Age at first sex, yrs } & \multicolumn{2}{|c|}{ Marital status } \\
\hline & Female & Male & $\leq 24$ & $>24$ & $\leq 19$ & $>19$ & Single & Married \\
\hline \multicolumn{9}{|l|}{$\begin{array}{c}\text { Knowledge of HIV } \\
\text { Status }\end{array}$} \\
\hline Yes & 74.3 & $62.9 *$ & 68.4 & 72.4 & 67.9 & 74.0 & 66.8 & $87.2 * *$ \\
\hline \multicolumn{9}{|l|}{$\begin{array}{c}\text { Knowledge of any } \\
\text { close relative with } \\
\text { HIV }\end{array}$} \\
\hline Yes & 17.1 & 18.9 & 17.5 & 16.9 & 22.9 & 19.7 & 16.1 & 26.3 \\
\hline \multicolumn{9}{|l|}{$\begin{array}{l}\text { Attended any HIV } \\
\text { programme }\end{array}$} \\
\hline Yes & 69.5 & 66.0 & 67.7 & 69.0 & 63.0 & 75.2 & 67.7 & 67.5 \\
\hline \multicolumn{9}{|l|}{ Knowledge of VCT } \\
\hline Yes & 71.1 & 78.6 & 72.9 & 75.6 & 75.5 & 73.8 & 75.4 & 71.8 \\
\hline \multicolumn{9}{|l|}{ Taken any HIV test } \\
\hline Yes & 70.7 & $63.5^{*}$ & 65.8 & 72.2 & 72.2 & 77.1 & 64.2 & $90.0 * *$ \\
\hline \multicolumn{9}{|l|}{$\begin{array}{l}\text { Knowledge of a } \\
\text { campus testing center }\end{array}$} \\
\hline No & 45.8 & 44.3 & 46.3 & 46.0 & 46.8 & 44.1 & 46.6 & 35.9 \\
\hline \multicolumn{9}{|l|}{$\begin{array}{l}\text { Tired of hearing } \\
\text { about HIV }\end{array}$} \\
\hline Yes & 25.2 & 25.9 & 24.8 & 25.2 & 26.9 & 29.5 & 25.6 & 25.0 \\
\hline \multicolumn{9}{|l|}{$\begin{array}{l}\text { At Risk of } \\
\text { contracting HIV }\end{array}$} \\
\hline Yes & 38.7 & $54.8^{*}$ & 41.3 & 51.2 & 50.5 & 48.6 & 45.3 & 42.5 \\
\hline \multicolumn{9}{|l|}{$\begin{array}{l}\text { Most preferred HIV } \\
\text { preventive strategy }\end{array}$} \\
\hline Condoms & 7.9 & 22.2 & 12.8 & 18.3 & 28.3 & 13.8 & 15.1 & 8.1 \\
\hline $\begin{array}{l}\text { Faithfulness to } \\
\text { partner }\end{array}$ & 40.5 & 24.8 & 31.7 & 37.5 & 26.4 & 44.2 & 28.9 & 73.0 \\
\hline Abstaining from sex & 51.6 & 51.6 & 55.5 & $42.5 * *$ & 44.3 & 41.3 & 56.1 & $18.9 * *$ \\
\hline
\end{tabular}




\subsection{Gender}

When asked questions on knowledge and awareness of HIV status, testing and testing centers (Table 2), female students knew their status more than their male counterparts $(p<0.05)$ and had also taken a HIV test more before $(\mathrm{p}<0.05)$. But when asked if one thought if he was at any sexual risk of contracting the virus, more males than females opted most $(54.8 \%$ vs. $38.7 \%$; $p<0.05)$. As regards, sexual intercourse, it was interesting to note that more male students said they had had previous vaginal sex, oral sex, more than 5 sexual partners, and preferred bisexual or homosexual intercourse than the female students. All the differences were significant at $\mathrm{p}<0.01$ (Table 3). However, about a quarter of the female students said they had been forced to have sex unlike $18.7 \%$ of their male counterparts $(\mathrm{p}<0.05)$.

On the pattern of condom use (Table 4), one of every three female students said they were ignorant of its proper use, compared to one in every ten male student $(\mathrm{p}<0.01)$.
Also, less females used condoms in their most recent sexual intercourse compared to males $(\mathrm{p}<0.01)$, and still more female students than males did not use a condom at all in the last 12 months $(31.5 \%$ vs. $11.7 \%$; p < 0.05$)$. When asked if one was happy using condoms, more males said "NO" ( $p<0.05)$.

\subsection{Age at First Sex Debut}

Students that had their first sex at an earlier age of 19 years and below, said they had tried oral sex before more than their counterparts $(53.6 \%$ vs. $40.1 \%$, p < 0.05$)$. A similar pattern was also observed when asked how may sexual partners they had kept in their life time.

Students with an earlier sexual experience had slept with more than five partners, with nearly $40 \%(\mathrm{p}<0.01)$ of them attesting to that (see Table 3). Lastly, students with earlier sexual experience compared to their counterparts, did not use a condom in their first sex $(70.1 \%$ vs. $45.4 \%$; $<<0.01)$.

Table 3. Demographic association of students' responses on their sexual behaviors in a Nigerian university

\begin{tabular}{|c|c|c|c|c|c|c|c|c|}
\hline \multirow{3}{*}{$\%$ response to survey questions } & \multicolumn{8}{|c|}{ Percentage response $(\%)$} \\
\hline & \multicolumn{2}{|c|}{ Gender } & \multicolumn{2}{|c|}{ Age } & \multicolumn{2}{|c|}{ Age at first sex } & \multicolumn{2}{|c|}{ Marital status } \\
\hline & Female & Male & $\leq 24$ yrs & $>24$ yrs & $\leq 19$ yrs & $>19$ yrs & Single & Married \\
\hline \multicolumn{9}{|l|}{ Previous vaginal sex } \\
\hline Yes & 60.3 & $77.2 * *$ & 58.3 & $85.8 * *$ & 94.5 & 93.8 & 63.9 & $90.0 * *$ \\
\hline \multicolumn{9}{|l|}{ Previous oral/anal sex } \\
\hline Yes & 27.3 & $41.3 * *$ & 31.2 & 39.8 & 53.6 & $40.1 *$ & 34.1 & 28.9 \\
\hline \multicolumn{9}{|l|}{ Number of lifetime sexual partners } \\
\hline 1-2 partners & 65.6 & 37.6 & 55.2 & 41.5 & 32.7 & 65.2 & 47.5 & 75.0 \\
\hline 3-4 partners & 23.4 & 24.8 & 22.8 & 29.2 & 27.9 & 24.6 & 25.1 & 18.8 \\
\hline 5 and above partners & 10.9 & $36.8 * *$ & 22.1 & 28.3 & 38.5 & $10.1 * *$ & 27.4 & $6.2 * *$ \\
\hline \multicolumn{9}{|l|}{ Sexual preferences } \\
\hline Heterosexual & 95.2 & 99.3 & 96.8 & 99.1 & 94.4 & 97.9 & 97.0 & 97.4 \\
\hline Homosexual/ Bisexual & 4.8 & $0.7 * *$ & 3.2 & 0.9 & 5.6 & 2.1 & 3.0 & 2.6 \\
\hline \multicolumn{9}{|l|}{ Forced sex in lifetime } \\
\hline Yes & 23.2 & $18.7 *$ & 21.9 & 22.3 & 28.7 & 21.3 & 20.8 & 28.2 \\
\hline
\end{tabular}

*P-values $<0.05\left(\chi^{2}\right.$ test $) ; * * \mathrm{P}$-values $<0.01\left(\chi^{2}\right.$ test $) ;$ Cronbach $\alpha=0.69$

\subsection{Marital Status}

Students who were either married or involved in a serious relationship said they had taken a HIV test before and knew their status more than single students $(90.0 \%$ vs. $64.2 \%, 87.2 \%$ vs. $66.8 \%$; $<<0.01$ respectively). On the issue of the best preventive strategies, more married and involved students thought faithfulness was the best $(73.0 \%, \mathrm{p}<0.01)$. When sexual behaviors were assessed, married and involved students were involved more in vaginal sex than single students $(90.0 \%$ vs. $63.9 \%$; p < 0.01 ) but had tried sex with lesser people in their life time than single students $(\mathrm{p}<0.01)$. Single students said they had used condoms in their most recent sex more than their married counterparts $(64.1 \%$ vs. $31.5 \%)$ and they also tended to be more consistent. All these responses were significant at $\mathrm{p}<0.01$. Patterns of condom use are displayed in Table 4. 
Table 4. Demographic association of pattern of use and attitude towards condom among students in a Nigerian university

Percentage response $(\%)$

\begin{tabular}{|c|c|c|c|c|c|c|c|c|}
\hline \multirow{2}{*}{$\%$ response to survey questions } & \multicolumn{2}{|c|}{ Gender } & \multicolumn{2}{|c|}{ Age } & \multicolumn{2}{|c|}{ Age at first sex } & \multicolumn{2}{|c|}{ Marital status } \\
\hline & Female & Male & $\leq 24$ yrs & $>24$ yrs & $\leq 19$ yrs & $>19$ yrs & Single & Married \\
\hline \multicolumn{9}{|l|}{ Knowledge of condom use } \\
\hline No & 33.5 & $11.0 * *$ & 27.3 & 13.6 & 9.2 & 9.7 & 25.5 & $12.5^{*}$ \\
\hline \multicolumn{9}{|l|}{ Condom use at first sex } \\
\hline No & 62.2 & 59.3 & 63.6 & 59.3 & 70.1 & $45.4 * *$ & 60.7 & 65.0 \\
\hline \multicolumn{9}{|l|}{ Condom at most recent sex } \\
\hline No & 48.3 & $22.9 * *$ & 39.6 & 30.4 & 32.4 & 26.8 & 31.5 & $64.1 * *$ \\
\hline \multicolumn{9}{|l|}{ Condom use in last 12 months } \\
\hline Never & 31.5 & 11.7 & 22.8 & 18.1 & 18.0 & 15.0 & 20.6 & 34.3 \\
\hline Irregularly & 36.5 & 39.8 & 38.6 & 36.2 & 43.0 & 38.3 & 34.4 & 51.4 \\
\hline All of the time & 32.3 & $48.4 *$ & 38.6 & 45.7 & 39.0 & 46.6 & 45.0 & $14.3 * *$ \\
\hline \multicolumn{9}{|l|}{ Embarrassed when purchasing condom } \\
\hline Yes & 44.2 & 29.1 & 38.4 & 33.0 & 38.0 & 35.4 & 36.4 & 45.9 \\
\hline \multicolumn{9}{|l|}{ Happy using condom } \\
\hline No & 50.8 & $65.2^{*}$ & 45.1 & 38.2 & 36.0 & 38.8 & 38.5 & $61.1 *$ \\
\hline
\end{tabular}

*P-values $<0.05\left(\chi^{2}\right.$ test);**P-values $<0.01\left(\chi^{2}\right.$ test $) ;$ Cronbach $\alpha=0.72$

\section{Discussion}

This study assessed the sexual behaviors of students of a University, their attitude towards HIV and pattern of condom use. Generally, the students indulged in risky sexual behaviors ranging from early sex encounters, multiple sexual partners and inconsistent condom use.

There was a later onset of sexual debut by these which was similar to results obtained in the Malagasy study but later than those reported with South African students whom over $50 \%$ had sex before the age of $16[6,15]$. This suggests that majority of the students who had lost their virginity, did so prior to and on admission to school. Early sexual onset in such a setting is often blamed on peer pressure, coercion and sudden "freedom" from parental scrutiny. Some studies have shown positive influence of parental supervision in various settings and their provision of protection from unhealthy behaviors by youths $[16,17]$. Majority of the students were single and this setting typifies one that will present students as youths without "borders".

The awareness of HIV/AIDS was poor in this setting, especially among single and male students. Female students tended to know more about their status because majority of them had previously taken a test before. We do not know if they had gone for the tests out of fear of the unknown or by compulsion, but Nigerian female youths are known to be self conscious. At this age, majority of the female students are looking forward to married life and we think the higher rates of testing in this group must have been to ensure they were "free of the virus". Married and engaged students however, are required by church "laws" to go for a test during courtship, and this may have warranted such a high knowledge of one's status in this group. Male students said they were at higher risk of contracting the virus with over half of them affirming to that. The remainder results of this study corroborate this claim as majority of male students were involved in one or more risky sexual events. However, majority of the students who felt they were at risk of contracting the virus used condoms consistently than those who said they were not at risk. This attitude has also been reported in some other African communities [18,19]. More singles clamored for abstinence from sex and married/engaged students preferred faithfulness to partners as best strategies for preventing spread of the virus. This is understood as married students cannot abstain from sex with their legal partners and single students know very well that abstinence is the best strategy for youths. From a gender perspective, majority of the students who thought faithfulness was the better strategy for preventing the spread of HIV were females. This perception by the female group makes them trust their male partners (who are likely to be more promiscuous, see results above) and not use any form of protection during sex and possibly increase their vulnerability to being infected.

In assessing involvement in risky sexual behaviors, it was observed that six of every ten student had tried vaginal sex before, with more males being involved than females. Naturally, males are dominant and high risk takers than females, and in such an environment as the 
university, restrictions on sexual activities are nearly nonexistent. Male students also accounted for high percentages engaged in multiple sex partnership. With more than one-third of them having an average of more than one sexual partner per sexual life, there is little wonder they see themselves as highly risked to contracting the virus. Also those who debuted in sex early were also involved in multiple sex partnership. So it could be assumed that the earlier a student's sexual life begins the probability of having many sexual partners later in their school life. Reasons for this high level of sexual promiscuity among these students were not assessed but we perceive that this may be indicative of students' (sexual) behavior in the university campus. Other risky behaviors such as involvement in oral and anal sex, sexual preferences and forced sex were also assessed. The prevalence of anal/oral sex was very high, found in at least one third of all students much more than those obtained in other settings $[5,20]$. Male students accounted for most of this behavior than females. These risky behaviors may increase the risk of contracting HIV as possibility of tear and blood contact is increased. Forced sex defined in the questionnaire as "have you forced or been forced to have sex before" was positively reported by one of every five of our cohort, with females accounting for most. It is not known what these students felt about forced sex or what actions they took after being forced into sex. This result was higher than those obtained from the Malawi study [5], and forced sex is usually associated with non-condom use and thus high risk of HIV transmission [21]. A small number of students (especially females, significantly) said they preferred non-heterosexual ways of having sex. This attitude calls for great concern, as those preferring them had already practiced them, not welcoming any room for change.

Knowledge of condom use was high among the cohorts with females differing most. Also use of condoms at most recent sex showed nearly $70 \%$ of students used protection, with more females failing in its use than males. Use of condoms during the last intercourse was assessed, as recall would be more accurate. Though these data are higher than those obtained from other endemic regions, where condom use in recent sex was found in only $50 \%$ of cohort [22], we should consider the setting, comprising youths that are properly exposed and educated. Street youths in Russia reported much lower condom use (48.8\%) [23]. The students in this study were much older and being older, have been associated with higher use of condom, especially at first sex [24]. However, majority of the students who said they used condoms in their most recent sex were students who used condoms in their first sex. This may show their consistency and understanding of the dynamics of the spread of the virus by these students. As much as one third of single students who were sexually active did not use protection in their most recent sex. Though this figure was much lower than those of the married/engaged students, this behavior may predispose these students to sexually transmitted diseases, unwanted pregnancy and possibly consideration of abortion when pregnancy occurs.

More females were involved with inconsistent ("never used" or "irregularly used") condom use more than male students. High and significant inconsistent use in married/engaged students may be understood as trust and been married is associated with free and unprotected sex. It is believed however that the engaged group may have accounted for majority of the responses on use of condom "all the time". However, consistent condom use obtained in this study was much higher than those obtained in students the Malagasy and South Africa, who reported $5.7 \%$ and $8 \%$ respectively [14], but similar to those seen in younger sexually active secondary school children in Kenya [24]. The incidence of inconsistent condom use among these students was high, and it has been variously documented that only consistent condom use even in the event of risky sexual behavior can effectively prevent the acquisition and transmission of HIV and other STDS $[9,10,11]$. Reasons and misconceptions for not using condoms among these students, though not assessed, may have been similar to those reported by students in Kenya and some Nigerian students [25,26]. A South African study confirmed some misconceptions associated with poor or no condom use ranging from "HIV link to witchcraft" and belief that "fresh fruits can cure AIDS" [27]. The majority of the students who felt they were at risk of contracting the virus used condoms consistently than those who said they were not at risk. This attitude has also been reported in some other African communities $[18,19]$. Also, students who claimed to use condoms during both their first and most recent sex, said they used condoms consistently throughout their sexually active period. The World Health Organization has also documented this trend [28].

Our sample was purposive and it was representative of the students in the final and penultimate years of the two departments that were used. The use of final and penultimate students was to assess these sexual behaviors when these students were in school. Some studies assessed first year students and this may not be reflective of the influence of the school on them rather it may only be reflective of pre-university life. This is also the first time a study comparing demographic variables of students in a university has been used to test students' awareness of HIV and their patterns of sexual behaviors and condom use. It thus provides a template for further studies to be conducted in other universities. However, the study suffered some limitations. Firstly, the information provided by the students were self-reported and may have some form of bias, either intentionally or by problems due to poor recall. However, we believe that our sufficient spacing and use of the ballot system created confidence and would have reduced intentional bias to the minimum. Secondly, results of this study conducted in one university, may not be generalized to other universities or higher institutions of learning in the region or country until such an explorative study has been carried out.

In conclusion, this study has shown that university students indulge in risky sexual behaviors and majority were not consistent users of condoms if at all they used them. Male students were less aware of their status and were more involved in risky sexual behaviors, with females showing poorer patterns of condom use. Governmental and non-governmental agencies are advised to re-focus HIV preventive strategies towards youths in universities. Universities should re-introduce awareness and enlightenment campaigns and HIV testing before and during program admission should be encouraged. Though sexual abstinence is the absolute way to prevent 
contracting the virus, consistent condom use should be encouraged as the students are well disposed to them.

\section{Acknowledgement}

The authors wish to thank staff and students of the Departments of Pharmacy and Sociology for their participation in the study.

\section{Competing Interest}

The authors have no competing interest.

\section{References}

[1] UNAIDS. Report on the Global AIDS epidemic, Geneva 2008.

[2] UNAIDS. “Africa Fact Sheet," March 2005.

[3] UNAIDS. At the Crossroads: Accelerating Youth Access to HIV/AIDS Interventions 2004.

[4] UNAIDS. Report on the Global AIDS Epidemic 2004: 4th Global Report (UNAIDS/04.16E). Geneva, Switzerland: UNAIDS 2004.

[5] Ntata PRT, Muula AS, Siziya S \& Kayambazinthu EE Gender differences in university students' HIV/AIDS-related knowledge and sexual behaviors in Malawi: a pilot study. J Soc Aspect HIV/AIDS 2008; 5 (4): 201-205.

[6] Rahamefy OH, Rivard M, Ravaoarinoro M, Ravaivoharisoa L, Rasamindrakotroka AJ, Morisset R. Sexual behavior and condom use pattern among university students in Madagascar. J Soc Aspect HIV/AIDS 2008;5 (1): 28-35.

[7] Ike SO, Aniebue PN. HIV/AIDS and sexual behaviour among Nigerian university students. Nig J Clin Pract 2007;10 (2): 105-10.

[8] Harding AK, Anadu EC, Gray LA, Champeau DA. Nigerian university student's knowledge, perceptions, and behaviours about HIV/AIDS: Are these students at risk? J Roy Soc Health 1999;119 (1): 23-31.

[9] Weller S, Davis, K. Condom effectiveness in reducing heterosexual HIV transmission. Cochrane Database Systematic Review, CD003255. In: National HIV and AIDS and STIs Strategic Plan for South Africa 2007-2011. Pretoria, South African National Government, 2002.

[10] Davis KR, Weller SC. The effectiveness of condoms in reducing heterosexual transmission of HIV. Fam Plann Perspect, 1999, 31 (6): 272-279.

[11] Pinkerton SD, Abramson PR. Effectiveness of condoms in preventing HIV transmission. Soc Sci Med; 1997, 44 (9): 13031312.

[12] Pettifor AE, Rees HV, Steffenson A, Hlongwa-Madikizela L, MacPhail C, Vermaak K, Kleinschmidt I. HIV and sexual behaviour among young South Africans: a national survey of 15 -
24 year olds. Johannesburg: Reproductive Health Research Unit, University of the Witwatersrand, 2004.

[13] Da Cruz, C. From policy to practice: the anthropology of condom use. In K. Kauffman \& D. Lindenauer (Eds.) AIDS and South Africa. The social expression of a pandemic. New York: Palgrave Macmillan, 2004. pp. 136-160.

[14] Bogale GW, Boer H, Seydel ER. HIV-prevention knowledge among illiterate and low-literate women in rural Amhara, Ethiopia. Afr JAIDS Res 2009; 8(3): 349-357.

[15] Eaton L, Flisher AJ, Aaro LE. Unsafe sexual behavior in South African youth. Soc Sci Med 2003; 56 (1), 149-165.

[16] Kingon YS, O'Sullivan AL. The family as a protective asset in adolescent development. J Holist Nurs 2001; 19 (2), 102-121.

[17] Harris L, Oman RF, Vesely SK et al. Associations between youth assets and sexual activity: does adult supervision play a role? Child Care Hlth Dev 2007; 33 (4), 448-454.

[18] Adih WK, Alexander CS. Determinants of condom use to prevent HIV infection among youth in Ghana. J Adolescent Health 1999; 24 (1), 63-72.

[19] Meekers D, Klein M. Determinants of condom use among young people in urban Cameroon. Stud Fam Plann 2002; 33 (4), 335-346

[20] Houston AM, Fang J, Husman C, Peralta L. More than just vaginal intercourse: anal intercourse and condom use patterns in the context of 'main' and 'casual' sexual relationships among urban minority adolescent females. J Pediatr Adol Gynecol 2007; 20 (5), 299-304.

[21] Dude A. Intimate partner violence and increased lifetime risk of sexually transmitted infection among women in Ukraine. Stud Family Plann 2007; 38 (2), 89-100.

[22] Stanton BF, Fitzgerald AM, Li X et al. HIV risk beaviours, intentions and perceptions among Namibian youth as assessed by a theory-based questionnaire. AIDS Educ Prev 1999; 11(2), 132149.

[23] Kissin DM, Zapata L, Yorick R. HIV seroprevalence in street youth, St Petersburg, Russia. AIDS 2007; 21, 2333-2340.

[24] Yotebieng M, Halpern CT, Mitchell EMH, Adimora AA. Correlates of condom use among experienced secondary school male students in Nairobi, Kenya. J Soc Aspects HIV/AIDS 2009; 6 (1), 9-16.

[25] Hawken MP, Melis RD, Ngombo DT et al. Opportunity for prevention of HIV and sexually transmitted infections in Kenyan youth: Results of a population-based survey. J Acq Immun Def Synd 2002; 31 (5), 529-535.

[26] Anugwom EE. Perception of AIDS among university students in Nigeria. Implications for AIDS prevention programmes. In C. Becker, J. P. Dozon, C. Obbo, \& M. Toure (Eds). Experiencing and understanding AIDS in Africa. Paris, Karthala and Codesria, 1999. pp. 589-597.

[27] Bogart LM, Skinner D, Weinhardt LS et al. HIV/AIDS misconceptions may be associated with condom use among black South Africans: an exploratory analysis. Afr J AIDS Res 2011; 10(2):181-187.

[28] World Health Organisation. Progress in reproductive health research: Sex and youth - misperceptions and risk. Geneva, Switzerland, 2000. 